\title{
What Does the Exchange Rate Do? A Status Symbol?
}

\section{Sikander Rahim*}

\begin{abstract}
This paper aims to assess the harmful impacts of exchange rate depreciations on Pakistan's economy, including impacts on international capital movements, wages, the domestic price level, and development. Devaluation of a currency in terms of foreign currencies or metallic standards was for long considered to be undesirable and, if unavoidable, a sign of failure. Attitudes have since changed and devaluation is thought to bring advantages, especially by making economies more competitive exporters. This paper is intended to show that it has disadvantages that outweigh any supposed advantages, notably its effects on inflation, income distribution, service on foreign debt and incentives. It does so by describing in concrete terms the relations between foreign and domestic prices and the costs of untradeable goods and services that are components of the price of any good in any domestic price index. It also discusses the motives, official and unofficial, that have prompted the monetary authorities of Pakistan to make a practice of regular depreciation of the rupee and to question their justification.
\end{abstract}

Keywords: Pakistan, exchange rate, depreciation.

JEL classification: E31, O24.

\section{Capital, Income, and Prices}

This paper describes some of the economic and social losses to a country from currency devaluation or depreciation and the mechanisms that cause them. During the time of fixed exchange rates-especially the first quarter-century after the Second World War-devaluation was something to be avoided. For governments, it was a sign of weakness; for the public, it was a national humiliation. Attitudes have changed since then. A lower price of a currency in terms of other currencies is thought to bring economic benefits and the readiness of the monetary authorities of low-wage countries to let their currency prices fall gains approval from the authorities of high-wage countries and from multinational institutions, most of all the International Monetary Fund (IMF)—all the more if it seems to be in response to the market. In many countries, including Pakistan, the

${ }^{*}$ Former Principal Economist, World Bank. 
monetary authorities take pride in this approval. However, there has been no systematic discussion of the harm that can follow and no empirical or theoretical assessment of whether Pakistan has benefited overall from the depreciation of its currency over the last 40 or so years.

We begin with a point of theory: the exchange rate is a macroeconomic quantity or variable. In principle, a change in the exchange rate results in changes in the price of tradable goods through the whole economy as well as in financial and fiscal quantities such as foreign debt and revenue from import duties. Why does this matter? It matters because it implies that partial equilibrium arguments cannot be used to discuss the effects of changes in the exchange rate; devaluation has effects throughout the economy and these have to be taken into account before anything can be said with confidence about the gains and losses that follow.

\subsection{Expectations and Capital Flight}

Devaluation leads to expectations about the future course of the exchange rate and, with this, can make further devaluation more likely. In the time of fixed exchange rates, when a country did devalue it was in the hope that the new exchange rate would be permanent. By the 1960s and 1970s, however, there was little doubt as to which countries would devalue again and which would not: expectations had been formed. Speculation on exchange rates became so profitable and the consequent capital movements so great that countries sometimes had to devalue to avoid losing all their international reserves. The inability to cope with these speculative capital movements caused the system of fixed exchange rates to be abandoned. Since then, any inhibitions about devaluing have been lost. Most highwage countries let their currency exchange rates be determined by the market, i.e., they let them "float."

The ways in which expectations are formed have also changed. In the case of Pakistan, as with many others, repeated devaluations gave rise to the expectation that the rupee would depreciate continually, which experience continued to justify and confirm. Until 1972, the official exchange rate was PRs 4.76 to the dollar, though, because of the Bonus Vouchers scheme, the rupee cost of the dollar was, for many imports, two or three times as high. With the abolition of the scheme in 1972, the exchange rate was fixed at PRs 9.91 to the dollar until 1981, after which it depreciated unsteadily. In 2000, it was about PRs 58 to the dollar; by March 2014, it was about PRs 105. No one doubts that the Pakistani rupee will continue to depreciate and if ever anybody had expectations of 
appreciation, except for occasional short fluctuations, it was long ago. Official attitudes confirm these expectations: depreciation of the currency is considered to be, in the case of Pakistan, somehow a good thing.

Speculative capital movements are a natural consequence of expectations of currency depreciation, but speculative capital from a highwage country can be expected to return home after the country devalues. This has happened each time countries such as France and the UK devalued in the 1960s or 1970s. In contrast, it does not happen after currency depreciations in countries such as Pakistan for which the expectation of further depreciation holds firm. In such countries, people with financial assets consider placing some of them in solid currencies such as the US dollar, euro, and yen.

At the least, this is prudent portfolio management through the diversification of assets. Exchanging rupees for dollars in 1982 (when Pakistan abandoned its fixed exchange rate) would have yielded, in 2000, an annual compound return in rupees of close to 10 percent. To this should be added the yield on foreign investment. Reliable figures are not possible but most higher-income families with members who occasionally travel abroad appear to have foreign bank accounts; some also own property in the UK, the US, and other places where foreign ownership is not restricted. In the short run, if devaluation is expected, any consequent gain can be exceeded by the loss of reserves from capital flight, as was the experience of several European countries during the time of fixed exchange rates. In the long run, the accumulated flight capital can exceed the country's foreign debt, which seems to have been the case for most Latin American countries and is probably true of Pakistan.

Most of the time, outflows of capital are impossible to detect and cannot be seen from the official national accounts or balance of payments (BOP). Over-invoicing imports and under-invoicing exports have been standard practices since the 1950s when imports began to be tightly restricted because of severe foreign exchange shortages, and they have not been the only ways of moving wealth out of the country. With the liberalization of the capital account, the government has virtually given up its ability to control capital movements.

Capital outflows that are not caught in the official statistics imply that gross domestic saving is higher than the low figures given by the national accounts. In Pakistan, as in many other countries where the collection of economic data does not receive enough attention, saving is 
calculated from the identity of the trade balance and the excess of saving over investment. Investment is estimated when the national accounts are put together and the data for imports and exports are obtained directly from customs or indirectly from the State Bank of Pakistan's data on external payments. If that part of saving that is lost abroad could be taken into account, the saving rate would be found to be that much higher than the rate calculated from trade and investment.

It is not surprising that gross domestic saving is, in reality, higher than the official figures. Early on, in the 1950s, when Ayub Khan's government formulated its Second Five-Year Plan, it was more or less explicit policy to concentrate income on the argument that those with higher incomes had higher saving rates than those with lower incomes, so that concentrating income raised the saving rate. Haq (1963), who developed this argument, asserted that, for rapid growth it was necessary "to shelve for the distant future all ideas of equitable distribution and welfare state" (p. 30). The government's foreign advisers had similar opinions; one of the most prominent stated: "Inequalities in income contributes [ $\mathrm{sic}]$ to the growth of the economy, which makes possible a real improvement for the lower-income groups" and the "concentration of income in industry facilitates the high savings which finance development" (Papanek, 1967, p. 242). Nowadays this may seem crude, but the saving rate does seem to have been raised, though the benefits have gone abroad.

\subsection{Nominal and Real Wages}

This policy of concentrating income was pursued with success under fixed exchange rates. Flexible exchange rates have allowed the same results without having to make them deliberate. Toward the end of the 1960s, international organizations such as the World Bank and many development economists began to criticize the extent of the inequalities that had become evident in many low-wage countries, apart from Pakistan. However, the same institutions and economists also advocated more flexible exchange rates, which meant that repeated devaluation and-since its primary purpose and effect are to lower nominal wages and other nominally fixed incomes relative to prices and wages outside the countrythe concentration of income has continued, though with more emphasis on development assistance and government policies to relieve poverty.

Examining wages gives an idea of how incomes are affected by exchange rates. It is reasonable to assume that changes in the wages of skilled and unskilled manual workers are a rough indication of how the income of the broad mass of the population changes. 
Although there are no good data on the wages received by unskilled and skilled manual workers for the period since the 1950s (which would otherwise have allowed a better understanding of the economy), it is possible to have a rough idea of how workers' pay has changed over time. The International Labour Organization (ILO) has published data given by the Pakistani authorities on monthly wages in manufacturing for 1969 to 2002, though the drops in some years and the amount of increase in others, as well as some gaps, make their accuracy uncertain. Assuming that the trends do indicate changes in the pay that unskilled workers receive in general, we can make three comparisons: (i) with income per head, (ii) with prices, and (iii) with foreign currencies, in this case the US dollar.

An increase in the ratio of nominal income per head, as given by the gross national product (GNP) per head in the national accounts, to the nominal monthly wage can be taken to show that the income per head of the mass of the population has not increased as much as that of people receiving higher incomes. In Pakistan, the ratio rose from the 1980s onward. Until the end of the 1970s, it had been below 6:1, but it increased after that, with fluctuations, to around 10:1 by 2000. Only in 1990 and 1995 did nominal increases in the nominal wage bring the ratio below 6:1.

The real wage, as calculated from the ILO data using the GDP deflator, changed in roughly the same way. After 1980, it fluctuated around the level it had reached at the end of the 1970s_again, at its highest in 1990 and 1995. Hence, the real wage rate increased as GDP increased in the 1970s (though with fluctuations) so that, from its lowest level in 1971 to its highest in 1978, it rose by about two thirds. After that, the years in which it was higher were offset by the years in which it was lower.

As mentioned already, increases in the nominal wage were offset by devaluation, with the cumulative effect that the wage was lower in terms of the dollar adjusted for US inflation in 2000 than it had been in 1970. Converting rupees into dollars at the official exchange rate, the monthly wage's lowest value, US\$ 22, occurred in 1972, though the fall from the previous years was a nominal effect of ending the Bonus Vouchers and devaluing the official rate. It then rose fast enough that, by 1979 , it had increased nearly 80 percent relative to the dollar deflated by the implicit US GDP price deflator. After that, nominal increases in dollar terms were smaller than the US rate of inflation. By 2000, the wage level had increased by 10 percent in nominal dollar terms from 1979 whereas the US GDP deflator had increased by 110 percent. Even starting from the 
lowest value of 1972, the wage increase in nominal dollars was less than that of the US deflator.

Employment outside Pakistan grew after 1973 but made little difference to unemployment and underemployment in the country. It added to the national product, in particular to the income of unskilled workers who were paid more than they would have been at home but normally had contracts of a few months at a time. These workers regarded such employment as a windfall of which part was to be saved and remitted home, often to buy a plot of agricultural or urban land or to build a house. Remittances alone have usually been close to half and mostly more than half of private unrequited transfers, which have been, in nominal terms, equivalent to 4-6 percent of GDP. There is no way of knowing, however, whether they had the effect of keeping wages in Pakistan from falling lower.

Using GNP as a measure of income, much (perhaps most) of the increase in income per head has gone to profit and to the wealthier owners of agricultural land, though the lack of detailed information of the sort provided in the US and Europe by income tax data prevents precise discussion. From 1979 to 2008, much of the middle class must have experienced a decline in income when measured in dollar terms and deflated by the US deflator, for the same was true for the country's income per head. In dollar terms, income per head rose by 83 percent by 2002 as compared to 110 percent for the US deflator; GDP measured in the same way rose 66 percent but was offset by the growth of population.

This kind of comparison must stop at 2000 because the economy's behavior during 2001/02 to 2007/08, as given by the national accounts, is different from all that went before or has happened since. During those years, the rupee appreciated slightly relative to the US dollar and then depreciated to roughly the starting point, but nominal income per head in terms of dollars doubled. Nothing near such a rate of increase in dollar terms had occurred before. One could conjecture that it shows the benefit of a stable exchange rate, but there has not been enough time to look at this exceptional rise in income in detail and it must be left out of the present discussion.

\subsection{Inflation}

Depreciation of a currency necessarily causes domestic prices to rise, i.e., inflation. There have been disagreements on this point, however, and empirical work using advanced statistical methods has led to quite different results. Ahmad and Ali (1999) conclude that devaluation does 
cause inflation whereas Choudhri and Khan (2002) find "no evidence of a significant pass-through of rupee devaluations to consumer prices in the short run" and conclude from this that "concerns about the inflationary consequences of devaluation in Pakistan are somewhat misplaced" (see the Appendix for a comment on this). Rather than enter into abstract models and statistical tests of their conclusions, the discussion here is an attempt to describe the actual components of costs and prices and how they are, or can be expected to be affected by, the exchange rate.

When the Pakistani rupee falls, the dollar, yen, or other foreign currency prices of imports do not, nor do the prices of Pakistan's exports, which are sold in competitive markets that are too big to be noticeably influenced by the rupee's exchange rate. However, the effects of devaluation on the domestic price of any good may be smaller than the actual devaluation or may be delayed. If, for example, devaluation raises foreign prices by 10 percent in rupee terms, the immediate or short-run effect may be to raise the prices of goods that go into calculating the consumer price index (CPI) or wholesale index by 2 percent and only a year later by a further 4 percent. The full 10 percent increase need never occur, though it may.

The reason for this is that the prices that go into any price index used to calculate inflation and the prices of goods bought by the ordinary consumer include an untradable component that is not directly affected by the exchange rate. To take the simplest example, that of an imported consumer good, the difference between the c.i.f. price (the price before any domestic costs or charges) and the price in a shop includes porthandling charges, storage and perhaps finance and insurance charges before transport to the shop. These are often the costs of the wholesaler or intermediary.

When sold as retail, the price must cover the cost of the people employed by the shop, the rent of the premises, utilities, insurance, and often packaging or wrapping. Even a single person selling from a roadside stall has to have a margin to make a living and to pay for the right to keep the stall where it is. With some consumer goods, such as shoes, the markup in a shop is around 100 per cent, so that the import price paid before any domestic costs or charges, that is, the c.i.f. price, is less than 50 percent of the final price.

Imported capital goods and intermediate goods used in production also incur some of the first set of costs-those before retail-though there 
may be no wholesaler or intermediary. Usually, they do not enter the CPI, barring exceptions such as different fuels of which the varieties used by consumers and producers are the same or closely related. Devaluation increases their c.i.f. prices in rupee terms and raises production costs.

If their final products are tradable consumer goods, producers may raise the prices of their products because the prices of competing imported goods have also increased. If the final product is not tradable, the higher production cost may not have an immediate effect, but it is to be expected that sooner or later the price of the final product will rise and the more producers are used to devaluation of their currency, the quicker will be the price rise. If the price rises caused by devaluation are spread over several years, the price increases of a recent devaluation may be compounded by the price increase caused by previous devaluations. Similar reasoning applies to the effects of devaluation on the prices of tradable goods that are not imported or are exported, for example, some types of textiles and agricultural or fishery products.

For the purposes of this discussion, the costs incurred at each stage between the border price of an import, i.e., the c.i.f. price, and the price to the final buyer can be decomposed into three elements: (i) the cost of space, that is, the rent of premises for storage and retail; (ii) the cost of labor of all sorts; and (iii) the profit margins. The same is true for the costs between the factory gate price of an export and its border or f.o.b. price.

The cost of space varies by location: it is higher in the centers of big cities than on the outskirts of small towns and storage space can be costly in big ports. It is also affected by monetary policy: when the monetary authorities allow credit to grow fast, the rent of urban land and buildings rises and so do their prices, perhaps even faster. Europe and the US showed this on a large scale between 2000 and 2007. When the monetary authorities restrain credit, these prices do not rise as much and, under the right conditions, may fall, perhaps abruptly.

Much of the cost between the ship and the retailer of an imported consumer good consists of payments for dockworkers and the cost of transport, security, and clerical work. There are similar costs between the factory gate and the ship for exports. The purpose of devaluation is to reduce these costs in terms of foreign currencies. It is, therefore, to be expected that the monetary authorities will try to restrain expenditure through monetary policy to prevent nominal wages and salaries from rising. Hence, this component of cost can be expected not to change in terms of the domestic currency. 
Since border prices in terms of foreign exchange do not change and, instead, rise relative to nominal wages, profit margins in the production of exports increase. Additionally, since we can assume that production does not fall when the authorities restrain expenditure, total profit increases. Profit margins in the production of goods that compete with imports also rise, though an expenditure restraint could cause demand to fall by enough that output is reduced and total profit does not rise proportionately. What happens to profits in the production of other goods in the short run depends on the specific circumstances. The prices of nontradable goods may rise a little or not at all at first, but they must rise in time with the prices of tradable inputs; as competition causes profit rates to become more even, the production of these goods will also increase.

Devaluation, therefore, causes inflation regardless of attempts to prevent it by restraining expenditure. Some of the price rises do not necessarily occur immediately, so that a single devaluation can result in inflation over several periods. Unless nominal wages rise to offset the price increase, one consequence is lower real wages.

\subsection{Financial Stocks and Flows}

Other economy-wide repercussions of changes in the exchange rate-apart from those discussed so far with respect to incomes and income distribution-include changes in the relation between financial stocks and flows when the correct or desired amount of the stock or flow depends on the exchange rate. This can cause resources to be misallocated. In a developing country, the three types of financial stocks affected by devaluation are external debt, the amortization of capital equipment, and savings.

\subsubsection{External Debt}

Devaluation raises the cost, in terms of the domestic currency, of debt denominated in foreign currencies and, even if the volume of domestic sales does not fall, only a rise in prices can prevent the liquidity and profits of nonfinancial businesses from declining. Well-established profitable firms, though they produce for the domestic market, are likely to be able to accommodate the effects of a single, moderate devaluation because their foreign currency debts are likely to be small, and, if they have problems, these firms usually have access to cash reserves or bank loans to tide them over until prices rise. New firms with foreign debt may not yet generate much, if any, profit, and are more likely to be bankrupted. 
Financing obtained from banks in terms of the domestic currency can have the same effects as foreign currency loans if the banks themselves have foreign currency debt. As a simple example, a bank that takes a fiveyear loan at 5 percent and lends it at 10 percent, with repayment in both cases in five equal installments, must raise its lending interest rate to 11.25 percent to cover the cost of its own borrowing if the devaluation raises the price of foreign currency by 25 percent. If the bank wishes to recover its margin of 5 percent to cover administrative costs, risk, and profit, its lending rate will be 16.25 percent.

Since devaluation is normally accompanied by demand restraint intended to keep prices from rising, the effects of the immediate rise in the cost of external debt combined with the slower rise in domestic prices are compounded by a fall in domestic sales. If the devaluation is large, firms become unable to stay current on their loans, banks restrict credit because of the spreading of credit problems, and the demand restraint that was meant to curb price rises, along with the rise in prices of imported inputs, turns the external financing into a source of widespread business failures.

\subsubsection{Amortization}

Since developing countries, as a rule, import practically all their plant and machinery from developed countries, the amortization for replacing existing equipment and the savings for buying new equipment must be adjusted to the exchange rate. However, amortization is rarely, if ever, adjusted in this way, so that the funds a prudently run firm sets aside to replace old equipment become insufficient if devaluation occurs.

Usually, equipment is amortized at historic cost in terms of the domestic currency. The shortfall for replacing it is then proportional to the devaluation. Amortizing at replacement cost may be difficult or impossible, even if the firm is eager to do it. One reason is that the firm would need to foresee the devaluation several years in advance. In a country that has not devalued for a long time, the expectation of devaluation may arise only weeks or months before the event, whereas the equipment may have been bought several years earlier. If a piece of equipment being amortized over five years is four years old and devaluation raises its replacement cost by 25 percent in terms of the domestic currency, its amortization in the last year would need to be 45 percent of its value.

If the firm has not placed this amount in its cash reserves, it will have to borrow from a bank or issue new shares. Issuing new shares is a 
cumbersome process and often disliked by existing shareholders, who do not want their capital diluted. Amortization is, however, a continuous process and so firms resort to more bank loans. The greater the rate of devaluation, the more indebted they will become.

Even if devaluation has been occurring regularly and the firm foresees the exchange rate correctly, amortization at replacement cost may be impossible because the authorities regulate how amortization may be calculated. They do so for good reasons, among them being that amortization affects the taxes paid by the firm and that rules are needed to protect shareholders, creditors, and the public. Hence, even if a firm wishes to amortize at replacement cost, it may be prevented by the rules and it will certainly be unable to persuade the authorities that its forecasted exchange rate should be used to calculate that cost.

\subsubsection{Savings}

Since devaluation causes inflation, it reduces the real value of savings in the form of cash, bank deposits, fixed-interest securities, and acquired pension rights-the principal financial savings of lower- and middle-income groups. If its purpose is to lower the prices of the country's tradables in terms of foreign currencies, this reduction is an unintended redistribution of wealth.

To some extent, adjusting the nominal value of the savings in step with prices can compensate for this. This is easier with pensions in a staterun defined benefits system, and such an adjustment would apply to workers producing tradables as to any others. Whether it will be financially sustainable in the future is a separate question that can only be answered by an independent assessment of the receipts and payments over the long run. Judging by the diminution in the real values of pensions in most countries that devalue frequently, it seems that wage earners and middleincome groups have merely been the losers in the redistribution of wealth caused by devaluation. Nevertheless, adjusting the nominal value of savings to compensate for higher prices may be impractical in most other cases since it would raise the liabilities of the institutions holding them without corresponding gains in their assets.

Alternatively, the real value of savings can be preserved by adjusting interest for inflation. In practice, this happens rarely; the interest received by lower- and middle-income groups in countries that devalue often does not suffice to offset inflation. The economic difficulties that led 
to and followed from devaluation have repercussions for the banking system, which protects itself, in effect, by reducing its liabilities to those who cannot negotiate their own terms for depositing with the banks.

\section{The BOP and the Currency}

What has to be explained is why Pakistan's currency has been allowed to depreciate more or less continually for so long. Even if depreciation did improve the balance of trade by increasing the quantity of exports and reducing the quantity of imports, there must be some additional reason that it continued. To this, the answer of the IMF and the monetary authorities is that depreciations offset domestic inflation, which is caused by letting the money supply increase. Their argument is that it is in politicians' nature to favor an increase in the money supply and that the central bank is not independent, or not independent enough, to prevent it from happening.

It is in accord with Friedman's assertion, crucial to modern central banking, that inflation is always a monetary phenomenon. Commonly, this type of argument is supported by using models in which prices are assumed to be proportional to the money supply and which, naturally, conclude that the exchange rate has to adjust to bring domestic prices in line with prices outside the country.

\subsection{Expenditure, the Trade Balance, and the Currency}

This reasoning cannot be applied to countries that do not have BOP restrictions. The simple argument that prices rise with the money supply is the old one of more money being used for a given supply of goods. This may be true of a closed economy but not of an open one for which the supply can be increased by importing more and exporting less. If more money results in higher demand for goods, some of that demand will be for tradable goods and will be met from the trade balance; the rest will be met by increasing the value of the output of nontradables by increasing their physical output and by raising their prices if the supply is constrained. In particular, the rent and, therefore, the prices of commercial and residential property may rise.

This is illustrated by the credit expansion in the US in 1999-2007, during which the Federal Reserve allowed, even encouraged, the growth of consumption and investment expenditure. One consequence was that the trade deficit, which had always been below US\$200 billion, rose to US\$ 750 billion in 2006. This meant that US residents bought more goods and 
nonfactor services than they produced; since supply was unconstrained, inflation was too low to be of concern. The current account deficit was still bigger, implying that US residents were incurring debt, which could go on as long as the central bank allowed credit to expand or until the increasing indebtedness of borrowers, especially households, led to a credit crisis.

Most often, as credit is allowed to expand, initially creditworthy borrowers incur too much debt to stay creditworthy while more and more borrowers who were not creditworthy receive loans. This is just the way financial institutions and people behave and has been for at least three centuries; years of excessive credit expansion have regularly been followed by crises. Much the same happened in Europe: the European Central Bank allowed credit in countries such as Greece, Ireland, Portugal, and Spain to expand at about the same time. These countries also had trade deficits and excessive household debt, though their government budget deficits (even that of Greece) were modest. In most cases, the budget deficits were smaller than that of Germany.

The difference that mattered, though, was that German households have always been more averse to debt and did not borrow in the same way. As former Federal Reserve chairperson McChesney Martin said, the job of the central banker is "to take away the punchbowl just as the party gets going." But, if the borrowing becomes excessive, the same central bankers who had allowed it to come this far must have the courage to be unpopular if it is to be reduced. The further the borrowing has gone, the greater the courage needed, for the more likely a crash. Galbraith (1961) remarked in this connection that it was not easy to deflate a bubble without it bursting.

Trade deficits have counterpart trade surpluses in other countries and, as is well known, the major counterpart of the deficits, especially of the US, was the surpluses of China. The excess of expenditure over production of the deficit countries was met by the frugality of the Chinese and the high growth rates of their economy. Politicians and economists of the West often blame the US deficits and China's surpluses on the Chinese government for keeping their currency "undervalued" although it is evident that the US was experiencing a credit boom, one fostered by the central bank, and that the US economy's saving rate had fallen close to zero. They do not explain how the exchange rate of the renminbi could have been the cause. To emphasize the point, the renminbi appreciated by about 20 percent in 2004, after which China's monthly current account surplus doubled on average. 
Pakistan, however, does have BOP restrictions that the US, Western Europe, Japan, and other high-wage countries do not. These countries' currencies are "hard," which means they are accepted for settling international transactions and large amounts can be exchanged for one another at the going exchange rates and continue to be accepted even when the exchange rates fluctuate. Exporters quote their prices in terms of some of these currencies, usually the US dollar, and expect to be paid in those, but importers in the other hard-currency countries can easily and at little cost obtain the currencies demanded in exchange for their own. Hard currencies are used by the monetary authorities of practically all countries as part of their international reserves.

Currencies such as the Pakistani rupee do not fall in this category and they are not normally accepted for settling international transactions. Exporters in countries whose currencies are not hard do not quote their prices in terms of the latter (even if it is their own currency), but in terms of hard currencies in which they expect to be paid. Monetary authorities do not include these currencies in their reserves. Foreign borrowing for financing specific payments or for the general BOP is also always in terms of hard currencies. Hence, any market for the rupee outside Pakistan is restricted to businesses or individuals connected to the Pakistani economy.

Consequently, the international payments of a country with a currency that is not hard are restricted at any time to that country's receipts of hard currencies (or "foreign exchange") and whatever reserves can be used to make payments then. As a first approximation, the amount of foreign exchange available in the short term-the next few months or year-can be taken as given. Anybody who has made economic projections for countries at the World Bank, prepared a stand-by arrangement at the IMF, or taken part in preparing the Government of Pakistan's annual plans is familiar with this. That part of total expenditure by the country's residents that is in excess of GDP is then spent on foreign exchange and, assuming the market is free and allowed to clear, it determines the price of the foreign exchange.

To describe this explicitly, the country's foreign exchange payments can be divided into the trade part, that is, imports of goods and nonfactor services, and the nontrade part, which includes debt service, repatriation of foreign capital, yields on foreign capital in the country, and payments for services rendered in the country by nonresidents. The foreign exchange receipts are exports and the nontrade receipts, primarily remittances by emigrants and workers abroad and foreign borrowing, especially foreign aid. These can also include the yield on investment abroad and foreign 
capital coming into the country. In the normal course of events, all these items can be taken as being out of the control of the authorities in the short run and as given and known. Leaving aside the use of reserves, foreign exchange payments are limited by foreign exchange receipts, which means that the foreign exchange available for the trade deficit (exports less imports) is equal to the net nontrade receipts.

At the same time, the total expenditure by the country's residents comprises goods and nonfactor services sold in the country (GDP at market prices less exports plus imports) and nontrade payments (GDP plus the total foreign exchange available, with an allowance for the use of reserves). Hence, if the amount by which expenditure exceeds GDP is greater than the value of net nontrade foreign exchange receipts at the initial exchange rate and if the government allows the foreign exchange to be bought and sold freely, the price of the foreign exchange adjusts for the market to clear, implying that the rupee depreciates. To the extent, therefore, that the monetary authorities determine expenditure, they also determine the exchange rate.

If the authorities do not allow a free market in foreign exchange and fix the exchange rate, they must have a procedure for distributing the foreign exchange when the demand for it exceeds the supply. The excess demand is met partly by forced saving and partly by diverting demand to nontradable goods, especially land and housing. If, however, foreign exchange is sold outside the control of the authorities on a parallel or black market, buyers will pay a premium.

An alternative, if the authorities have good control over the foreign exchange, is to sell it on the market. If they acquire it at the fixed rate, they can use the market to eliminate the excess demand by converting the premium into revenue, provided that revenue is not spent. This could be done through regular auctions designed to meet the demand in a dependable way. It would be one of a variety of multiple exchange rate practices, which the IMF forbids because they create distortions and, hence, economic inefficiency, and which it has tolerated only in special cases. Economic inefficiency apart, it can help a country avoid the need for BOP support when the authorities have trouble curtailing domestic expenditure, especially budgetary outlays.

The monetary authorities have some flexibility when they have a free market: they can use or add to reserves and they can control expenditure, at least to some extent. Pakistan's reserves are too small to be 
more than precaution against illiquidity, but some countries have accumulated reserves equivalent to several years' worth of imports, which allows their authorities to use those reserves to prevent depreciation of the currency when the expenditure would otherwise result in depreciation.

Such reserves are useful for coping with unforeseen events, though they carry a cost in terms of goods exported of equivalent value. Expenditure can, in principle, be kept below the sum of GDP and the available foreign exchange, the unused foreign exchange being added to the reserves. In this case, it is mainly imports that adjust. Such a restriction of expenditure can, equally, have the effect of lowering GDP. It depends on the degree to which the goods that are imported compete with domestically produced goods. If, for example, the latter are basic items of consumption whereas luxury items are imported, and if the expenditure restrictions affect, above all, the upperincome groups, domestic production may be unaffected.

There are also the unofficial and illegal markets dealing in foreign exchange and contraband, which affect the official markets indirectly. Part of the supply of foreign exchange can be remittances that do not go through official financial institutions, though they may be legal. It may be illegal for residents to have investments or property overseas, in which case the income from them, if brought into the country, will be brought in clandestinely. There is also the clandestine transfer abroad of wealth, which can be simply to diversify assets or avoid losses caused by depreciation or can be to launder money obtained illegally, i.e., "black" money. Usually, the monetary authorities try to have some estimates of the amounts involved and to anticipate how events or their own actions might affect them.

\subsection{The Money Supply, Exchange Rates, and Inflation}

From this, it follows that the money supply is associated with inflation through two different mechanisms. First, a larger money supply, through its effect on total expenditure by residents, means that foreign exchange will cost more and domestic prices will be higher. Second, the causation can go the other way: because foreign prices have risen relative to domestic prices, which may have been a result of the currency depreciation or of inflation outside the country, the monetary authorities will allow the money supply to increase to avoid liquidity problems. Nasim (1996) uses statistical techniques to provide empirical evidence of this in a study commissioned by the State Bank of Pakistan, although his conclusion, that "money supply would appear to be a key determinant in an economy" (p. 1) is meant to support the simple idea that prices are directly related to the quantity of money. 
No statistical techniques are needed to see from the study's data that they confirm that higher foreign prices in terms of the domestic currency are associated with inflation. Devaluation of the rupee and inflation in the rest of the world caused prices, as indicated by the CPI, to rise in the country. The study's description of events over 1970-95 shows that high inflation in Pakistan is always associated with devaluation or high international inflation and low inflation with a stable exchange rate and low international inflation, although this is not what the author concludes from his description.

The association with money supply is not as close: in certain periods (1977-79, 1982-83, 1992-93), inflation and money supply did not move together. Figure 1.d of the study plots the CPI and the rupee prices of tradable goods (a proxy for international prices) over time and shows that the CPI follows the prices of tradables with a short lag. No such relation is apparent in figure 1.b, which plots the CPI against the money supply; rather it is the contrary movements that stand out.

Nasim (1996) does not attempt to assess explicitly the extent to which the exchange rate could have affected prices. The study mentions the first mechanism as the cause of "simultaneity bias" for which it has no answer. It seems to exclude the second mechanism on the grounds that prices adjust to money supply, apparently because of Friedman's argument that a rise in the price of one good leaves less money to be spent on other goods, whose prices must, therefore, fall. Not only is this argument incompatible with the assumption that the prices of tradables are determined by world prices, but it also ignores the possibility that the quantities bought, not the prices, change.

Inflation occurs if the monetary authorities allow expenditure to exceed the sum of GDP and the foreign exchange available at the current exchange rate, thus causing the currency to depreciate, which is the first mechanism. If the monetary authorities increase the money supply because prices have risen, which is the second mechanism, the result can be further depreciation and inflation. Taken too far, it can result in accelerating inflation, which must be stopped by using the reserves or obtaining enough foreign financing to meet the excess of expenditure over GDP at the exchange rate of the moment.

Normally, the authorities try to prevent or slow down inflation and do not, therefore, allow expenditure to grow that fast. They bring about a permanent cycle of moderate depreciation and inflation. If they believe that inflation in the country is faster than a suitable measure of inflation 
outside, they may want the currency to depreciate. They may try, on the one hand, to keep inflation low by not allowing expenditure to increase too much; on the other hand, they may not restrain it enough to prevent further depreciation.

It is much the same if the authorities fix the exchange rate and there is excess demand for foreign exchange. If there has been inflation, the authorities may devalue but still allow enough expenditure for there to be excess demand for foreign exchange at the new exchange rate. If there is a black market, the excess demand will be expressed as a premium, which is sometimes interpreted as being an indicator of the true value of the currency, although it is merely the result of monetary policy.

Another reason that the cycle can be self-perpetuating is that inflation does not directly indicate how the prices of the country compare with the relevant prices outside. It is not inflation, which is the relative movement of price indices, that should be the concern, but the comparison of the actual level of prices in the country with prices elsewhere. Failing direct price comparisons, it is possible that the prices of nontradables in the country have been lowered more than need be in terms of foreign currencies and that the same is true of the prices of tradables that take longer to adjust.

Such price comparisons as have been made seem to confirm that this is the case for Pakistan: the prices of nontradable goods are low by the standards of most countries, especially of the high-wage countries, and the prices of tradable goods that are relatively high are mainly those of imports. The major exception has been the price of electricity, which has at times been relatively high, supposedly to attract foreign investment. If the currency were to stop depreciating, prices in the country would continue rising for some time: the prices of tradables as they adjusted to the prices of other comparable tradables and the prices of nontradables as the prices of their tradable inputs rose. However, since comparing the movement of price indices is easier and quicker than comparing prices directly, depreciation continues.

Friedman's assertion that inflation is always a monetary phenomenon is seen to be wrong. When a country devalues, its prices must rise, even if they fall at first in terms of foreign exchange. Normally, one would expect the rise to be mitigated by the nontradable components of all wholesale and retail prices, such as the cost of local transport and the rent of commercial space, and by the reduction of nominal wages in terms of foreign currencies. Thus, the retail prices of goods can fall in terms of 
foreign currencies because the rent of retail space does not go up in proportion to the price of foreign exchange, but they still go up in terms of the domestic currency because the landed cost or export prices go up. Reducing the money supply might perhaps slow down the price rises, which would be a sign of inefficiency in adjusting to the changed exchange rates, but it cannot prevent them. What it does is reduce the rate at which transactions are carried out.

In theory, there is no assurance that any particular prices fall in foreign currency terms. Nominal wages decline relative to prices and, if this decline is permanent, the consequence is a higher rate of profit on capital. In an efficient economy, this diffuses through to all productive capacity and raises prices where they have not already been raised by the effects of competition from imports and exports. Nontradable goods do not compete directly with imports, so the prices of those goods the production of which is capital-intensive rise relative to the prices of those of which the production is labor-intensive. In principle, the price of an nontradable good can rise by more than the devaluation (i.e., in terms of foreign exchange) if the production is sufficiently capital-intensive. Nothing in theory prevents such price rises from causing the nontradable components of retail prices from rising so as to increase some retail prices of tradables in the same way.

This raises the following question: what influence do central banks have over inflation? In countries with hard currencies, a large enough credit expansion can cause rents and property prices to rise as well as perhaps prices on the stock market, while the trade deficit deteriorates and domestic indebtedness grows, though inflation remains at its usual rate. As can be seen at present, central banks cannot raise the rate of inflation when they want to. McChesney Martin's dictum makes no mention of inflation and the financial crises in both the US and Europe show that financial stability and inflation are separate matters.

Jean-Claude Trichet, the head of the European Central Bank at the time of the financial crisis of 2007, has illustrated this point. His response some time after the end of his term to criticisms of his management of monetary policy was that his mandate had been to keep the inflation rate close to but below 2 percent, which he had fulfilled. In countries with currencies that are not hard, central banks can and do cause inflation by allowing expenditure to exceed GDP by more than the amount of foreign exchange available and causing the price of foreign exchange to rise. 
This discussion has followed the effects of devaluation through the economy in conformity with the point made at the start, that the exchange rate is a macroeconomic quantity. Proponents of the equilibrium exchange rate (EER) appear to acknowledge this macroeconomic nature because they believe that, as Krugman (1990) states, "the equilibrium real exchange rate at some time in the future will be foreseeably different from today's real exchange rate" and "that policy toward the nominal exchange rate can somehow facilitate the adjustment toward this future real exchange rate" (p. 160).

Friedman (1953) asserted something similar, namely that the exchange rate has a "final position" and that the market takes it there ( $p$. 162). He added that "fundamental factors" could change this final position. Both Friedman and Krugman seem to imply that the final position or EER is something inherent to the economy. This is true also of the variety of EERs that others have proposed, all relying on what are termed "fundamentals." What these have in common is that they are all considered characteristics of the economy in some fundamental way.

Krugman explicitly refers to the EER as a real quantity, as do all other EER proponents, but there is no agreement on what the fundamentals might constitute. Each of the various EERs has its own list of fundamentals, some including the difference in interest rates between countries, others including the share of GDP consumed by the government, the terms of trade, the relative prices of tradables and nontradables, the ratio of output per head in the production of tradables to that of nontradables (as an indicator of the difference in technical progress between the two sectors), or even the old-age dependency ratio and the stage of development (represented by GDP per head).

Among the EERs are the fundamental EER, desired EER, behavioral EER, equilibrium real exchange rate (ERER), and the natural real exchange rate, to mention only some of the older ones. The IMF has tried to impose order by setting up an authoritative body, the Consultative Group on Exchange Rates (CGER), to choose a list of fundamentals that would also be authoritative, though it is not clear with what success, since establishing a real exchange rate by committee, in this case the ERER, does not stop others from thinking up new fundamentals and EERs.

Such diversity is a sign that there is no such thing as an EER. If there were, it would be possible to deduce from it the fundamentals and the mechanism by which the exchange rate affected the BOP. That there cannot be such a thing is seen from the way each country's EER is 
calculated independently of the rest. Since the trade and current account balances of all countries must add to zero, no country's BOP can be taken in isolation from the rest, though this is what is done by using each country's fundamentals to calculate its particular EER.

Similarly, calculating the same type of EER for different countries using the same fundamentals ought to yield mutually consistent exchange rates. However, when this kind of calculation was made, for instance, by the CGER, the exchange rates were not consistent and had to be modified to make them so. EERs are also incompatible with the normal effects of monetary policy on the trade balance. Increasing or decreasing expenditure in a country with a hard currency or ample reserves reduces or increases the trade balance; in a country that does not have a hard currency and does not use its reserves to accommodate the expenditure changes, it is the exchange rate that changes.

\section{Motives and the Consequences for Development}

In Pakistan, as in many other countries, the precondition for the continual depreciation of the currency was a change of attitude toward exchange rates. Until the late 1970s, nearly all countries had tried to keep their exchange rates constant, while economic doctrine asserted that persistent trade deficits had to be remedied by devaluation and surpluses by revaluation. As mentioned at the start, during the time of fixed exchange rates, having to devalue was seen as a sign of weakness, and that as much in France and the UK as in Pakistan or Madagascar. At the same time, countries resented having to revalue because it reduced profits. On the whole, countries were initially successful in keeping their exchange rates fixed; after devaluation by the UK and some other countries in 1949, France was the only other high-wage country to devalue before the 1960s and that because of political events.

The frequency of devaluation began to rise after the early 1960s. Several high-wage countries had to devalue in the late 1960s and 1970s because speculative capital flows had grown so large as to exhaust their reserves. There was a pattern: it was usually the same countries that had repeated deficits and devalued, so these were also the countries least able to accumulate the reserves needed to cope with speculative capital flows. There was rarely any doubt about which countries were likely to devalue or be made to devalue next. Nevertheless, faith in the efficacy of devaluation did not diminish. On the contrary, it led to the replacement of the Bretton Woods system of fixed exchange rates by market-determined or floating exchange rates. In place of the motive for fixed exchange rates- 
namely avoiding competitive devaluation of the sort that was believed to have added to the economic difficulties between the two world warsemerged the new orthodoxy that the markets would get the exchange rates right and bring stability.

From the late 1970s onward, more and more countries let their exchange rates float. Pakistan's exchange rate, which had been fixed at PRs 9.91 to the dollar since 1972, was allowed to depreciate from 1982 onward. The attitude toward fixed exchange rates had changed in Pakistan and this appeared to be a logical consequence of the removal of administrative controls over foreign exchange transactions, particularly the liberalization of the current account. Fixed exchange rates required controls for dealing with excess demand for foreign exchange and it seemed logical that, once the controls were removed, adjusting the price (the exchange rate) would bring demand and supply together. It seemed equally logical that domestic inflation-to the extent that it exceeded inflation outside the countryshould be offset by letting the currency depreciate.

From what was said earlier, one can see that these apparently logical conclusions are simple examples of the failure to understand the macroeconomic nature of the exchange rate. In particular, they neglect the undesirable effects of depreciation. Official pronouncements on monetary policy and exchange rates never paid attention to these effects and neither government officials nor their economic advisers showed any awareness of them. A change had taken place, the aversion to devaluation and concern about the repercussions giving way to willingness to devalue, without acknowledging or even being aware that some of the repercussions might be undesirable.

The change has been partly symbolic. The old opposition to devaluation has been inverted. Governments disliked devaluation because they thought of it as a sign of weakness and poor economic performance. Now, in Pakistan and similar countries, the weakness is taken for granted with depreciation its normal consequence. Willingness to let the currency depreciate is judged a sign of realism and, therefore, of maturity, especially by such upholders of the orthodoxy as the multilateral organizations, notably the World Bank and the IMF, and other official development agencies on which countries such as Pakistan depend.

Continual depreciation of the currency has become an indicator of how the officials of a country regard its status; if they regard their country to be a weak economy, the currency depreciates. For such a country to let its currency appreciate would be presumptuousness. When the rupee 
appreciated slightly against the dollar in 2002 and 2003, the change was quickly reversed. When, by the logic of their own orthodoxy, Pakistan's monetary authorities should have revalued-namely during the high international inflation of the 1970s-rather than do so, they complained about having to "import inflation." Revaluation would have been at odds with the country's status.

The history of the initial industrialization of the present industrial countries shows that they almost never changed their exchange rates. Only during the chaotic period between the two world wars did changing exchange rates come to be regarded as sometimes necessary. While industrializing before the First World War (1914-18), these countries were, for the most part, on gold or silver standards and the notion that the exchange rate was in some way a quantity that had to be adjusted according to fundamentals or price indices was unknown. These countries developed because the incomes of a large part of the population, not just of the elite, rose as they developed. On the one hand, growing middle classes with rising incomes and workers earning higher wages raised the demand for more and better goods; on the other, rising wages, including better working conditions, stimulated the invention of better production methods. From these came new industries and improved products.

This is a kind of progress in which cause and effect cannot be quantified or represented by a mathematical formula and it was even greater after the Second World War, when the US, Western Europe, and Japan had fixed exchange rates and decades of fast economic growth with full or close to full employment and low inflation. The incomes of the great majority of their populations rose in step with GDP and, as far as it can be quantified, technical progress in the form of new or improved goods and better production methods was faster than ever before.

In Pakistan, as in many other countries, the process has been the reverse: the exchange rate has been used to keep wages down so as to keep to the old industries. Here is a comparison with the history of the highwage countries that cannot be made using formalized methods to capture rigidly the functioning of economies: such formulae, equations, and diagrams postulate relations that do not exist, simplify to keep the mathematics manageable and, by almost always being cast in a single period, ignore time and, therefore, the consequences of events. What this shows instead is the most pernicious consequence of repeated devaluation. 


\section{References}

Ahmad, E., \& Ali, S. A. (1999). Exchange rate and inflation dynamics. Pakistan Development Review, 38(3), 235-251.

Choudhri, E. U., \& Khan, M. S. (2002). The exchange rate and consumer prices in Pakistan: Is rupee devaluation inflationary? Pakistan Development Review, 41(2), 107-120.

Friedman, M. (1953). The case for flexible exchange rates. In Essays in positive economics (pp. 157-203). Chicago, IL: University of Chicago Press.

Galbraith, J. K. (1961). The great crash, 1929. Boston, MA: Houghton Mifflin.

Haq, M. (1963). The strategy of economic planning: A case study of Pakistan. Karachi: Oxford University Press.

Krugman, P. R. (1990). Equilibrium exchange rates. In W. H. Branson, J. A. Frenkel, \& M. Goldstein (Eds.), International policy coordination and exchange rate fluctuations (pp. 159-196). Chicago, IL: Chicago University Press.

Marsh, D. (2009). The euro: The politics of the new global currency. New Haven, CT: Yale University Press.

Nasim, A. (1996). Determinants of inflation in Pakistan. Karachi: State Bank of Pakistan.

Papanek, G. F. (1967). Pakistan's development: Social goals and private incentives. Cambridge, MA: Harvard University Press. 


\section{Appendix}

\section{A Comment on Choudhri and Khan (2002)}

In their article referred to here, Choudhri and Khan state that concerns about devaluation causing inflation in Pakistan are "misplaced," which must be taken to mean that devaluation does not cause inflation. This conclusion is the reverse of the usual widely held belief that devaluation normally causes inflation. Even central banks such as the Bundesbank have, on occasion (and especially before the creation of the euro), expressed the worry that a depreciation of the German currency would cause prices in Germany to rise (see, for example, Marsh, 2009, pp. $37,75)$. Similar opinions in newspapers are common enough. A recent example, taken at random, is given in the Financial Times of 7 February 2014, in which James Mackintosh in his column "The Short View" quotes the head of the European Central Bank, Mario Draghi, on how the exchange rate affects prices.

The conclusion raises several questions about how the economy of Pakistan fits in with the rest of the world. If Pakistan's price level is unaffected by devaluation, is there not an inconsistency between domestic and border prices? If it is the foreign market that determines the prices of Pakistan's exports, such as textiles and rice, why do they not go up in the country? There must be some relation between domestic and foreign prices and, if so, does devaluation not create new distortions? Is the conclusion true of Pakistan alone or is it true of all countries or of some countries but not others? If it is not true of all countries, as Draghi, Mackintosh, and others imply, how is it that depreciation causes inflation in high-wage countries but not in a low-wage country such as Pakistan?

What has to be explained is how the statistical results come about and exactly what they say. This is, as is often the case when statistical results are suspect, a question about specification. In theory, a statistical exercise should test a specified hypothesis, which, in this case, should be a mechanism describing how the exchange rate does or does not relate to domestic prices. Here, there is no specification in this sense. Instead, it is a search for a possible connection between the rate of change of the CPI on the one hand and the lagged rates of change of the exchange rate, of an index of foreign consumer prices, and of Pakistan's CPI on the other.

According to basic economic reasoning, domestic prices of tradable goods will rise because the border prices of imports and exports rise in 
terms of the domestic currency after devaluation. The mechanism is described briefly in this paper. A correctly specified test should, therefore, use border prices, not the CPIs of other countries that have no connection to the Pakistani economy. If the composite index made out of these indices is to be a proxy for border prices, some evidence should be given for how good a proxy it is. Since the exchange rate affects the relation between border and domestic prices but has no independent effect, the specification should not include it. If devaluation increases domestic prices, the relation to be tested should be between the change in border prices in terms of the domestic currency and the appropriate domestic price index, not between their rates of change.

The rates of change are related too, but not closely if there are lags. It takes more advanced techniques to determine whether the data indicate a significant relation when there are lags and variations in the rate of change of the exchange rate and, hence, of border prices. This also holds when the speed at which domestic prices respond to changes in the border price varies as a result of monetary policy, which is not included in the regression. The difficulty is greater when a composite index of foreign consumer prices is used. There is also no reason that the rate of change of the CPI in the current period should be affected by the rate of change in previous periods, which should not, therefore, be included in the regression.

Finally, the lags are limited to four, which confines the conclusions to the short term, i.e., one year. It would be surprising if devaluation did not take longer to have its full effect on prices. Usually, two years or more are thought necessary. Even if the regression were to indicate that more lags do not improve the statistical results and if the conclusion that concerns about the effect of devaluation on inflation being misplaced could be accepted for the short term of about one year, the results of the regressions do not justify extending the conclusion beyond that. ${ }^{1}$

1 A confession: the author's study of statistics and econometrics ceased before cointegration, Dickey-Fuller tests, etc., were invented. 